\title{
Kritik Sosial Dalam Kumpulan Puisi Karya Taufiq Ismail
}

\author{
Mellysa Aditya K
}

M. Agung Mukti

Syahlulya Lully E

Universitas Negeri Malang

\begin{abstract}
Abstrak
Kumpulan Puisi Taufiq Ismail yang berjudul"Bagaimana Kalau, Kembalikan Indonesia Padaku, Malu Aku Jadi Orang Indonesia, Kita Adalah Pemilik Sah Republik ini dan Zaman Edan"ini memiliki latar belakang kritik sosial yang disampaikan pengarang. Tujuan dari penelitian ini adalah untuk menjelaskan kritik sosial pengarang yang terdapat dalam kumpulan puisi Taufiq Ismail. Pendekatan yang digunakan adalah Sosiologi Sastra. Penelitian ini menggunakan metode penelitian kualitatif. Penelitian ini dikaji dengan menggunakan teori Lucien Goldman tentang pandangan dunia (sosial) pengarang berupa kritik sosial. Sumber data yang digunakan dalam penelitian ini kutipan bait dalam puisi tersebut. Hasil dari penelitian ini adalah kritik sosial dalam kumpulan puisi Taufiq Ismail. Penelitian ini menitikberatkan pada pandangan dunia pengarang puisi dengan keadaan yang ada di dunia ini dengan banyaknya kritik sosial yang ada dalam masyarakat. Adanya keresahan masyarakat terhadap keadaan negara yang sudah campur aduk dan berantakan, sekalipun banyak orang yang membuka suara hanya menambah kerunyaman. Kumpulan puisi ini mengungkapkan kekesalan penulis kepada Negara yang dihancurkan oleh masyarakatnya sendiri, masyarakat yang memiliki sikap tidak baik. Sikap khawatir terhadap Negara yang sudah berantakan dan akan dipegang kendali di tangan orang-orang yang tidak bertanggung jawab.
\end{abstract}

\section{Kata Kunci: kritik, Sosial, Puisi, Sosiologi Sastra}

PENDAHULUAN

Karya sastra diciptakan oleh

pengarang sebagai media untuk mengekpresikan atau menuangkan perasaannya, salah satunya bentuk karya sastraberupa puisi. Puisi merupakan karya sastra yang bahasanya terikat oleh irama, rima serta menggunakan kata-kata kiasan dalam larik dan baitnya. Menurut Waluyo (2005:1) puisi adalah sebuah karya sastra dengan menggunakan bahasa yang dipadatkan, dipersingkat dan diberi irama dan pemilihan kata-kata kias atau imajinatif.

Fungsi sosial karya sastra banyak melibatkan kehidupannya ditengah-tengah masyarakat, dalam aspek sosial juga memiliki rasa toleransi dalam lingkungan masyarakat (Semi, 1989 : 56). Karya sastra selalu hadir dalam kehidupan masyarakat, dengan melibatkan hal apapun untuk menjadi sebuah karya sastra.

Salah satunya puisi sebagai media untuk mengkritik kehidupan sosial yang 
ada di dunia sesuai dengan perkembangan jaman. Kritik sosial merupakan bentuk komunikasi pengarang atau masyarakat dengan tujuan sebagai alat kontrol terhadap jalannya sebuah sistem (Oksinata, 2010:33). Masalah kritik sosial terjadi apabila kenyataan yang dihadapi oleh masyarakat tidak sesuai dengan harapannya.

Menurut Laely Nurul (dalam Ahmat Sodiqin (2006: 4-5) kritik sosial dalam puisi tidaklah berhenti pada kritik semata, melainkan memiliki tujuan yang lebih jauh lagi, yaitu menampilkan dimensi pendidikan bagi masyarakat luas. Kritik dalam puisi atau kritik pada umumnya, menjadi bahan pertimbangan tersendiri bagi penerima kritik dan menjadi pelajaran bagi pihak lain.

Hubungan masyarakat dengan sastra adalah salah satu hubungan yang bisa dituangkan melalui tulisan ataupun lainnya. Masyarakat mempunyai hubungan erat dengan karya sastra dan kehidupan. Karya sastra selalu hadir dalam kehidupan masyarakat, dengan melibatkan hal apapun untuk menjadi karya sastra. Pengarang sebagai salah satu masyarakat yang mengekspresikan kritik sosialnya melalui kumpulan puisi diantaranya "Bagaimana Kalau, Kembalikan Indonesia Padaku, Malu Aku Jadi Orang Indonesia, Kita Adalah Pemilik Sah Republik ini dan
Zaman Edan" yang diciptakan oleh Taufiq Ismail.

Sosok Taufiq Ismail merupakan penyair dan tokoh sastrawan angkatan 66 . Salah satu karyanya yaitu puisi yang diciptakan dengan bahasa yang sederhana dan memiliki pemaknaan yang mendalam dalam setiap puisinya. Menurut Teeuw (1989:58) ungkapan yang disampaikan pengarang melalui sebuah puisi untuk pemusatan perhatian pada pesan demi pesan itu sendiri.

Peranan sastra dalam kehidupan masyarakat banyak memberikan manfaat untuk para pembaca. Sastra juga mempunyai gambaran tentang kehidupan masyarakat yaitu memiliki suatu kenyataan sosial (Sapardi Djoko Damono dalam Pradopo, 2001:157). Sastra sebagai penggambaran kehidupan masyarakat untuk mengungkapkan gagasan, ide atau sebuah pikiran dalam masyarakat.

Sastra yang baik berupa sastra yang dapat menciptakan kerjasama dengan masyarakat. Sastra menyajikan kehidupan dan sebagian besar terdiri dari kenyataan sosial (masyarakat) walaupun karya sastra meniru alam dan subjektif manusia (Wellek dan Warren, 1990:109). Dunia sastra sebagian besar banyak mengungkapkan dengan kenyataan sosial. Setiap pengarang menghasilkan karya sastra yang bermutu sehingga semakin 
berkembangnya produktivitas dan kualitasnya.

Sebuah puisi dapat dikatakan menyenangkan yaitu jika sifatnya menghibur dengan mengemukakan sesuatu yang menarik atau mengagumkan, namun sebuah puisi juga memiliki nasehat-nasehat yang berupa dorongan moral atau berupa pengajaran akan kebenaran dan yang mempunyai manfaat (Alfiyan Rokmansyah, 2014:28).

Rumusan masalah dalam penelitian ini adalah bagaimana kritik sosial dalam kumpulan puisi Taufiq Ismail?. Salah satu manfaat dari penelitian ini adalah untuk mengetahui kritik sosial dalam kumpulan puisi Taufiq Ismail.

Penelitian ini belum pernah di lakukan oleh siapapun, oleh karena itu penelitian ini dibuat bertujuan untuk menganalisis kritik sosial pengarang dalam kumpulan puisi karya Taufiq Ismail.

Penelitian ini penting dilakukan untuk mengetahui kritik sosial yang disampaikan pengarang dalam kumpulan puisi Taufiq Ismail dan memberikan informasi kepada pembaca bahwa didalam kumpulan puisi antara lain "Bagaimana Kalau, Kembalikan Indonesia Padaku, Malu Aku Jadi Orang Indonesia, Kita Adalah Pemilik Sah Republik ini dan Zaman Edan" terdapat kritik sosial yang tajam akan keadaan Indonesia saat itu.
Pendekatan yang digunakan dalam penelitian ini adalah pendekatan sosiologisastra. Sosiologi sastra menurut Sapardi Djoko Damono dalam Wahyuningtyas dan Santoso (2011:20) yaitu ilmu pengetahuan yang mempelajari masyarakat dalam keseluruhannya, terutama yang berhubungan dengan dengan aspek-aspek masyarakat yang menyangkut dengan interaksi di lingkungannya.

Penelitian ini menggunakan teori Lucien Goldman. Teori ini akan mengkaji tentang permasalahan pandangan dunia pengarang berupa kritik sosial yang terjadi dalam kumpulan puisi Taufiq Ismail. Teori Lucien Goldman ini menekankan pada pandangan yang diekspresikan melalui kelompok sosial dalam bentuk pemikiran, perasaan, tingkah laku. Adanya keterkaitan pemikiran kritis pengarang yang ingin disampaikan dan permasalahan kehidupan sosial masyarakat yang berhubungan dengan kumpulan puisi Taufiq Ismail.

\section{KAJAN PUSTAKA}

Penelitian ini menggunakan teori Lucien Goldman yang menjelaskan bahwa pandangan dunia diekpresikan melalui kelompok sosial yang termanifestasi dalam bentuk sebuah pemikiran. Goldman menekankan bahwa karya sastra yang asli yang menggambarkan struktur mental yang 
terletak dalam perilaku sosial salah satunya berupa bentuk kritik sosial.

Lucien juga berasumsibahwa sosiologi sastra yang dimiliki adalah bentukpandangan dunia seorang masyarakat yang mengemukakan gagasangagasan, aspirasi-aspirasi dan perasaan yang menghubungkan secara kelompok sosial tertentu dan mempertentangkan dengan kelompok sosial lainnya menurut Goldman via Faruk (1999:15) yang berkaitan dengan kumpulan puisi Taufiq Ismail yang berjudul "Bagaimana Kalau, Kembalikan Indonesia Padaku, Malu Aku Jadi Orang Indonesia, Kita Adalah Pemilik Sah Republik ini dan Zaman Edan"

Goldman juga mengembangkan konsep pandangan dunia dari situasi sosial dan ekonomi tertentu yang dihadapi oleh subjek kolektif yang memilikinya. Pandangan dunia tidak lahir dengan tibatiba, transformasi mentalis yang lama perlahan-lahan tergantikan yang baru. Maksud dari konsep tersebut adalah struktur global yang bermakna, seperti pemahaman dunia secara total yang mencoba makna dengan segala kerumitannyan.

Pandangan dunia , menurut Junus (1988:16) terikat pada masa dan ruang tertentu, dalam masa terikat dengan sifat sejarahnya dan menghubungkan sejarah sebagai subjek kolektif suatu karya sastra tercipta. Untuk memahaminya tidakseorang pun dapat secara komprehensif pandangan dunia atau hakikat dari suatu karya satra tersebut.

Pendapat Goldman dalam (jurnal CMES, 2014:33) beranggapan bahwa manusia tidak mungkin mempunyai pandangan dunianya (world view) sendiri. Goldman mencoba mendapatkan pandangan dunia dari pengarangnya. Penulisan itu sendiri bukanlah seorang individu yang berdiri sendiri. Ia adalah bagian dari suatu kelompok sosial yang memiliki pandangan yang sama.

Konsep pandangan dunia Goldman juga menghubungkan kehidupan masyarakat dengan karya sastra itu sendiri. Perkembangan jaman juga mendukung faktor terciptanya sebuah karya satra dari segi isi maupun strukturnya, strukturalisme genetik itu sendiri pandangan dunia yang dianggap hubungan antara kelompok sosial yang memilikinya dengan situasi sosial dan ekonomi pada saat tertentu (Goldman dalam Faruk 1999:13).

Penggunaan teori Lucien Goldman ini dapat membantu dalam menentukan pandangan pembaca tentang kritik sosial yang disampaikan pengarang dalam kumpulan puisi Taufiq Ismail dengan menggunakan situasi sosial dalam permasalahan karya sastra tersebut.

\section{METODE PENELITIAN}


Kumpulan puisi karya Taufiq ismail ini menggunakan jenis penelitian kualitatif. Pendekatan penelitian yang digunakan dalam menganalisis kumpulan puisi karya Taufiq Ismail ini ialah dengan menggunakan pendekatan sosiologi sastra. Penyelesaiannya penelitian ini menggunakan teori Lucien Goldman dengan asumsinya dengan permasalahan tentang pandangan dunia sosial pengarangdalam permasalahannya berupa kritik sosial yang dituangkan dalam puisi tersebut.

Sumber data pada penelitian ini adalah kumpulan puisi Taufiq Ismail dengan judul antara lain; Bagaimana Kalau, Kembalikan Indonesia Padaku, Malu Aku Jadi Orang Indonesia, Kita Adalah Pemilik Sah Republik ini dan Zaman Edan. Hal yang akan diteliti dalam puisi tersebut adalah kritik sosial pengarang yang terdapat didalamnya.

Teknik pengumpulan data yang digunakan dalam penelitian ini yaitu dengan studi dokumen. Studi dokumen meneliti data yang berupa berbagai macam dokumen yang menjadi bahan analisis. Langkah dalam studi dokumen 1) membaca secara keseluruhan kumpulan puisi Taufiq Ismail, 2) Mencari bagian tertentu yang terdapat dalam puisi yang berkaitan dengan kritik sosial, 3) menandai bagian yang termasuk dalam kritik sosial dan mencatat ulang hasil yang sudah ditandai tersebut.

Untuk mengecek keabsahan data, pertama kali sebelum menentukan dan memutuskan analisis data, dilakukan pemeriksaan keabsahan data untuk mengetahui kebenaran dan keakuratan data yang diperoleh dalam penelitian ini dengan cara triangulasi data. Ketiga triangulasi tersebut antara lain: (1) triangulasi teori, (2) triangulasi sumber data, dan (3) triangulasi peneliti. Melalui langkah uji validitas tersebut, peneliti bisa lebih muda mendapatkan data tentang teori yang cocok sebagai acuan penelitian. Triangulasi data dilakukan sejak pengumpulan data sampai analisis data dilakukan.

\section{HASIL DAN PEMBAHASAN}

Secara umum puisi karya Taufiq Ismail tersebut mengungkapkan gambaran keresahan masyarakat yang dituangkan Taufiq Ismail. Dalam setiap puisinya Taufiq Ismail mengungkapkan bagaimana krtitik sosial yang dihadapi masyarakat diantaranya kumpulan puisinya yang berjudul antara lain: "Bagaimana Kalau, Kembalikan Indonesia Padaku, Malu Aku Jadi Orang Indonesia, Kita Adalah Pemilik Sah Republik ini dan Zaman Edan”.

\section{A. Kritik sosial dalam Kumpulan Puisi Taufiq Ismail.}

\section{Puisi "Bagaimana Kalau"}


Bait puisi yang diciptakan oleh Taufiq Ismail yang berjudul “ Bagaimana Kalau" terdapat sindiran atau kritik masyarakat yang dituangkan dalam bait:

Bagaimana kalau hutang-hutang

Indonesia dibayar dengan pementasan

Rendra,

Dapat dilihat dari bait tersebut kekesalan yang dirasakan masyarakat akibat hutang Indonesia yang tak kunjung selesai dalam bentuk bait dengan sindiran di atas. Masyarakat seolah - olah ingin membayarkan hutang Indonesia dengan pementasan yang dilakukan oleh W.S Rendra. Dikemukakan oleh Soekanto (1992:79) bahwa setiap masalah sosial yang meresahkan masyarakat dan memiliki perubahan suatu saat akan terjadi apabila kenyataan yang dihadapi oleh warga masyarakat berbeda dengan apa yang mereka harapkan. Sependapat dengan yang dikemukakan Soekanto bahwa masalah sosial yang menimbulkan adanya kritik yang dilakukan oleh masyarakat akan terjadi jika permasalahan terjadi di lingkungannya ataupun negaranya yang dituangkan dalam bentuk kritik sosial tertulis melalui tulisan dalam bentuk fiksi maupun non fiksi, prosa maupun puisi.

\section{Puisi "Kembalikan Indonesia Padaku”}

Ungkapan seorang pengarang untuk menggungkapkan sebuah kekesalan terhadap Negara yang mulai rusak dan yang mulai tidak seperti dulu lagi, banyak orang-orang yang ingin menghancurkan negaranya sendiri.

"Hari depan Indonesia adalah dua ratus juta mulut yang menganga"

Bait 1 dari puisi "Kembalikan Indonesia Padaku. Menggambarkan bahwa dua ratus juta mulut yang menganga menandakan jumlah penduduk yang akan kehilangan kecakapannya di dalam berkomunikasi karena sudah tercengang melihat kondisi yang serbah campur aduk. Ketika emua orang didekte oleh pemimpin sehingga mereka kehilangan potensi, kreativitas, dan keberanian mereka untuk mengaktualisasikan apa yang meraka miliki.

"Hari depan Indonesia adalah
pertandingan bola pingpong siang
malam"
Pada bait 5 dari puisi "kembalikan
Indonesia Padaku”. Menggambarkan masa depan Indonesia akan semakin terancam di tanggan orang-orang yang suka memepermainkan nasib orang banyak, di tangan oangyang tidak memiliki hati, apalagi yang dipermainkan adalah potensi, kreativitas, calon pemimpin bangsa. Membelenggu kreativitas, membelenggu potensi seseorang sama halnya dengan menghancurkan masa depan bangsa. 
Bukanlah masa depan bangsa terletak pada generasi mudanya.

Pada hakikatnya penyair ingin mengkritik kebijakan pemerintah, pembuatan kebijakan sistem dan aturan. Penyair ingin mengatakan bahwa jangan sampai kebijakan itu membelenggu kreativitas manusia yang hidup dibawah naungan NKRI. Karena pada akhirnya Indonesia tidak dapat menghasilkan generasi bangsa yang berkualitas generasi bangsa yang memiliki semangat untuk menjadikan Negara semakin baik.

\section{Puisi Malu aku jadi orang Indonesia”}

Bentuk kritik sosial masyarakkat juga terjadi dalam puisi Taufiq Ismail yang berjudul "Malu aku jadi orang Indonesia",

Kejahatan bukan kelas maling sawit melainkan permainan lahan duit

Dalam kutipan tersebut jelas bahwa dalam era yang sudah terjadi masyarakat menganggap bawa kejahatan sudah tidak dianggap tabuh lagi melainkan sebagai pekerjaan bagi orang tertentu yang melakukannya. Kritik yang terjadi di kehidupan masyarakat ini menunjukkan sebuah kejahatan tidak ditakuti lagi, melainkan sebagai wadah untuk menghidupi keluarganya. Seakan-akan masyarakat yang tinggal dibawah naungan tersebut tertekan dengan keadaan yang dialami Indonesia. Malu aku jadi orang
Indonesia dapat terlihat dalamawal judul yang dituangkan oleh Taufiq Ismail memberikan kesan yang dituangkan dalam puisi tersebut. Kekesalan yang terjadi akibat ulah masyarakat itu sendiri.

\section{Puisi "Kita dalah pemilik Sah Negeri} Ini”

Kritik sosial dalam kumpulan puisi Taufiq Ismail yaitu puisi yang berjudul “ Kita adalah pemilik sah negeri ini”. Pada bait:

Apakah akan kita jual keyakinan kita

Dalam pengabdian tanpa harga

Akan maukah kita duduk satu meja

Dengan para pembunuh tahun yang

lalu

Dalam setiap kalimat yang berakhiran

"Duli Tuanku ?"

Bait tersebut Taufiq Ismail mengungkapkan untuk menyadarkan masyarakat agar merennung terdapat tindakan yang sudah dilakukan selama ini. Bait tersebut juga menunjukkan bahwa "kita" mengkhianati negeri kita sendiri dengan duduk satu meja dengan para pembunuh tahun lalu artinya bahwa pembunuh tahun lalu yaitu negara yang sudah menjajah Indonesia selama berpuluh- puluh tahun lamanya, dengan membiarkan mereka masuk ke Negara kita dan dengan halus menjajah Indonesia kembali dengan berupa kerja sama. 
Taufiq Ismail mengungkapkan rasa kecewanya terhadap masyarakat. Masyarakat dianggapnya tak berani bersatu yang seharusnya masyarakat yang berkuasa di negeri Indonesia. Dalam bait selanjutnya taufiq Ismail mempertegas bahwa tidak ada pilihan lain, semua masyarakat harus terus maju dan semangat dalam memperjuangkan dan mempertahankan negeri ini.Puisi ini juga mendukung sifat kepatriotismean dari setiap baitnya Taufiq Ismail menggunakan kata kata yang terlihat mengajak kita sebagai warga Indonesia untuk mempertahankan negeri Indonesia.

\section{Puisi "Zaman Edan"}

\section{Hidup di zaman edan \\ Suasana jadi serba sulit \\ edan tak tahan \\ Tak ikut \\ Tak kebagian \\ Malah dapat kesengsaraan \\ Begitulah kehendak Allah \\ Sebahagia-bahagia orang lupa \\ Lebih bahagia orang sadar dan waspada}

Dalam puisi karya Taufik Ismail yang berjudul "Zaman Edan" digambarkan bahwa kehidupan pada saat zaman edan atau zaman yang dirasakan oleh kebanyakan orang sebagai situasi yang tidak menentu, penuh kecemasan dan ketidak pastian. Pada zaman edan menunjukkan bahwa orang pandai belum tentu sukses. Yang sukses adalah orang yang cerdik dan licik, sedangkan orang jujur meski pekerja keran namun hidupnya sengsara. Banyak orang yang berjiwa baik dan bijaksana, justru kalah dengan mereka yang culas, kerdil, dan jahat Itulah sebabnya orang yang baik-baik justru tersisihkan dan berada di belakang atau tenggelam oleh ramainya dunia yang penuh angkara murka atas silau pesona maya dunia.

Pada zaman edan, orang kaya sangat mudah mendapatkan pekerjaan namun orang miskin susah untuk mendapatkan pekerjaan. Orang miskin malah mendapatkan kesengsaraan. Korupsi semakin merajalela yang dilakukan oleh orang kaya raya. Mereka semakin banyak menguras uang negara. Harta bendanya semakin menumpuk namun masih ingin yang lebih tanpa peduli dengan orang miskin. Keserakahan telah menutupi hatinya.

Pada zaman edan, moral tidak dipentingkan lagi. Tidak ada persahabatan lagi dan tidak ada kawan abadi. Kawan bisa menjadi lawan, dan yang tadinya lawan bisa menjadikan kawan asalkan menguntungkan. Banyak terjadi musibah, bencana, dan malapetaka yang datang bertubi-tubi, silih berganti tiada hentihentinya, baik yang disebabkan oleh 
murkanya alam maupun oleh kelalaian manusia yang rakus dan angkara. Terjadi banyak peristiwa keanehan, ajaib, tidak masuk akal, banyak orang yang stres dan putus asa, atau tidak bernalar sehingga serba sulit untuk bertindak. Keadaan seperti itu menyebabkan orang-orang menjadi gila, edan, atau tidak ada yang waras. Rumah-rumah sakit jiwa dipenuhi dengan pasien yang menderita gangguan jiwanya.

Berbagai keadaan tersebut tidak lepas dari tangan Allah, karena Allah-lah maha segalanya. Tetap mengasuransikan jiwa dan raga kepada-Nya dalam keadaan apa pun.

\section{KESIMPULAN}

Pada dasarnya setiap puisi memiliki suatu kesan yang ingin disampaikan oleh pembaca, rasa kecewa, rasa kekesalan dan lain-lainnya. Masyarakat sebagai pembaca karya sastra yaitu sekumpulan manusia yang saling bekerjasama dalam jangka waktu yang panjang. Hubungan masyarakat dengan sastra adalah salah satu hubungan yang bisa dituangkan melalui tulisan ataupun lainnya. Masyarakat mempunyai hubungan erat dengan karya sastra dan kehidupan.

Salah satu karya sastra yang berupa Puisi sering digunakan untuk media estetis untuk mengungkapkan ekspresi baik berupa aspek sosial maupun protes terhadap keadaan yang ada disekitar pengarang. Puisi juga menggunakan media untuk menuangkan perasaan bisa dalam baris-baris sajak, pada dasarnya merupakan ungkapan kejujuran, sebuah ketulusan yang dituangkan oleh pengarang. Kumpulan puisi Taufiq Ismail dengan judul: "Bagaimana Kalau, Kembalikan Indonesia Padaku, Malu Aku Jadi Orang Indonesia, Kita Adalah Pemilik Sah Republik ini dan Zaman Edan”. Kritik sosial yang terkandung dalam setiap puisi memiliki tujuan tertentu untuk masyarakat yang ada di Indonesia ini. Dengan media puisi sebagai ungkapan kritik yang dijalani oleh masyarakat selama ini.

\section{DAFTAR PUSTAKA}

Akbar Syarizal, Retno Winarmi \& Andayani. 2013. Kajian Sosiologi Satra Dan nilai Pendidikan dalam Novel " Tuan Guru Karya Salman Faris". Jurnal pendidikan bahasa dan sastra, (Online), 1(1): 56-68, ( http://jurnal.pasca.uns.ac.id) diakses pada tanggal 02 April 2018.

Aliyah, L. N. (2010). Kritik Sosial dalam Kumpulan Sajak Terkenang Topeng Cirebon Karya Ajib Rosidi: Tinjauan Sosiologi Sastra. 1-27.

Asri, Y. (2012).Kritik Sosial dalam Kumpulan Puisi Aku Malu Jadi Orang Indonesia Karya Taufik Ismail. 35-43.

Atar Semi, 1989. Kritik Satra. Angkasa bandung. 
A.Teeuw.1984. Sastra dan Ilmu Sastra. pengantar teori Sastra. Jakarta : Dunia Pustaka Jaya.

Faruk, Pengantar Sosiologi Sastra. Pustaka Pelajar:Yogyakarta 2012

Goldman, Lucien. 1977. The Hidden God. Routled and Kegan Paul: London. Junus, Umar. 1989. Stilistik: Pendekatan, teori, metode, teknik dan kiat. Yogyakarta:

Unit

penerbitan sastra asia barat.

K.S. Yudiono.2009.Pengkajian Kritik Sastra. Jakarta: Gramedia.

Oksinata Hantisa. Kritik Sosial Dalam Kumpulan Puisi Aku Ingin Jadi Peluru Karya Wiji

Tukul. Skripsi tidak diterbitkan. Surakarta: Fakultas Keguruan dan Ilmu Pendidikan.

Universitas Sebelas Maret.

Pradopo, Racmat D. 1993. Pengkajian

Puisi. Yogyakarta: Gadjah Mada University Press.

Saini K. M. 1986. Protes Sosial dalam Sastra. Bandung: Angkasa.

Soekanto, Soerjono, 1992, Kamus Sosiologi, Jakarta: PT. Raja Grafindo persada.

Waluyo, Herman J. 2005. Pengkajian Sastra Rekaan. Salatiga: Widyasari Press.

Wahyuningtyas, Wijaya. 2011.SASTRA:

Teori dan Implementasi. Surakarta: Yuma Pustaka.

Wellek, Rene dan Austin Warren. 1995.

Teori kesusastraan. Jakarta: 